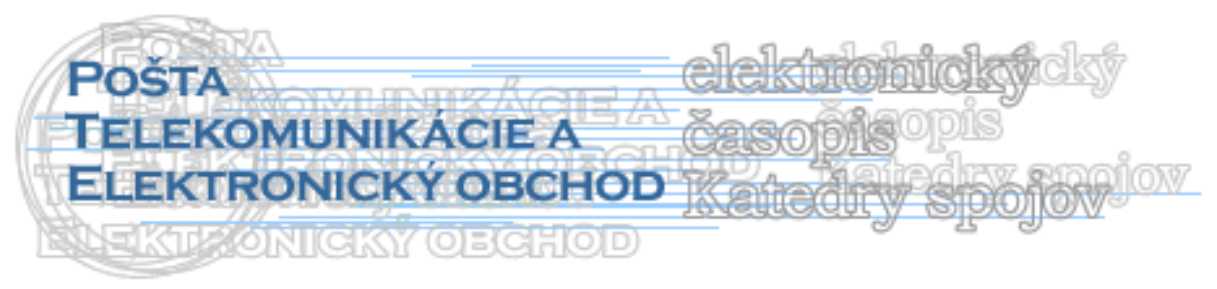

\title{
MARKETINGOVÝ KOMUNIKAČNÝ MIX AKO SÚČASŤ PODNIKOVEJ KOMUNIKÁCIE
}

\author{
Jaroslava Vidová*
}

\section{Úvod}

Mnoho rokov existuje rozpor medzi expertmi na marketingovú komunikáciu a expertmi na reklamu. Prvá škola je známa pod označením aktívna marketingová komunikácia tvrdí, že marketingový komunikačný mix obsahuje celú paletu, jasne definovaných ciel'ov komunikácie. Aktívna marketingová komunikácia je vhodná pri navrhovaní kampane marketingovej komunikácie, pri ktorej sa predáva služba.

Druhá škola sa zameriava na definovanie ciel'ov reklamy a na meranie reakcií na reklamu. Táto teória je známa pod skratkou DAGMAR - Defining Advertising Goals Measuring Advertising Response/Results. Využíva sa, ak je reklama využívaná na zmiernenie pochýb o výhodnosti nákupu. Kampaň zameraná na vzbudenie primárneho dopytu, ktorá má zvýšit' všeobecný záujem o vynikajúce vlastnosti produktov, nemôže byt' z pohl'adu úspešnosti hodnotená podl'a kritérií zvýšenia predaja. Časový posun medzi uskutočnením nákupu určitého produktu je príliš dlhý.

Oba typy kampaní sú vhodné a každá z nich zohráva svoju úlohu v marketingových programoch. Výsledky aktívnej kampane sú l'ahšie meratel'né. Uskutočnený predaj možno merat' kvantitatívne a je l'ahšie sumarizovat' počty objednávok, než merat' zvýšené povedomie l'udí. Na druhej strane si však zamestnanci marketingových útvarov musia vždy uvedomovat', že podstatou filozofie DAGMAR je jasné vymedzenie ciel'ov v časovom predstihu, pretože pravdepodobnost' neúspechu pri výbere meradiel sa značne zvyšuje.

Snahou každého podniku je dosahovat' ekonomickú efektívnost', ktorá je podmienená predajom určitého množstva tovaru. Na dosiahnutie plánovaného objemu predaja podnik využíva rôzne komunikačné prostriedky a rôznu štruktúru komunikačného mixu.

\section{Podniková komunikácia}

Komunikácia je proces prenášania informácie od jednej osoby (skupiny) k druhej osobe (skupine). Efektívna komunikácia je odoslanie správy takým spôsobom, aby prijatá správa bola svojím významom vel’mi blízka zamýšlanej správe. [3]

Komunikácia má dvojaké poslanie:

- interné, v podniku ul'ahčuje vykonávat' jednotlivé manažérske funkcie a ich vzájomnú integráciu,

- externé, umožňuje interakciu podniku s vonkajším prostredím, čím sa podnik stáva

\footnotetext{
* Ing. Jaroslava Vidová, PhD., Technická univerzita v Košiciach, Strojnícka fakulta, Katedra manažmentu a ekonomiky, Němcovej 32, 04200 Košice, tel.: +421556023231, fax: +421556023233 e-mail: Jaroslava.Vidova@tuke.sk
} 
otvoreným systémom. V tomto prípade sa zist’ujú potreby zákazníkov, možnosti dodávatel'ov, požiadavky akcionárov, vládne obmedzenia a pod. Externé poslanie komunikácie je neobyčajne významné pre vedenie podniku.

Komunikácia prebieha vždy v určitom kontexte a v prostredí, ktoré môže v niektorých prípadoch spôsobit' zabrzdenie, prípadne aj zlyhanie komunikačného procesu. Bariéry $\mathrm{v}$ interpersonálnej komunikácii sú tvorené nasledovnými faktormi:

- Účinok statusu - vzniká vtedy, ked' je jedna osoba funkčne postavená ovel'a vyššie ako druhá.

- Sémantické problémy - ked' l'udia používajú ten istý výraz v rôznych situáciách alebo rozdielne výrazy na objasnenie toho istého problému.

- Percepčné prekrútenie - môže byt' spôsobené nedostatočným pochopením seba samého alebo iných l'udí.

- Kultúrne rozdiely - komunikácia medzi l'ud'mi z rôznych vnútropodnikových organizačných jednotiek, napr. oddelením výskumu a rozvoja a výrobou, nakol'ko pracovníci oddelenia výskumu a rozvoja musia pracovat' koncepčne $\mathrm{z}$ hl'adiska dlhodobého časového horizontu, kým výrobný manažér musí riešit' úlohy operatívne, denne. Kultúrne rozdiely sa môžu prejavit' aj medzi l'ud'mi s odlišnými skúsenost’ami pôsobiacimi v rozdielnom sociálnom a náboženskom prostredí.

- Fyzické prekrútenie - môže vzniknút' v prípade značného hluku, v nedostatočne izolovaných miestnostiach, kde je počut' hluk áut, slabé osvetlenie, počut' hluk písacieho stroja zo susednej miestnosti, kde je vel'ký pohyb l'udí prichádzajúcich $\mathrm{s}$ malichernost'ami a s perom $\mathrm{v}$ ruke alebo na kávu v najmenej vhodnom čase pre komunikáciu.

- Slabý výber komunikačných kanálov - ak chcete získat' okamžitú reakciu od príjemcu a pritom nechcete poslat' rozsiahlu správu, chceli by ste pravdepodobne zdvihnút' telefón alebo íst' povedat' do kancelárie ako a čo treba robit'. Treba mat' na pamäti, že jeden obrázok je vyjadrením tisícky slov a vo veku počítačov môže byt' grafická informácia zhotovená ovel’a rýchlejšie týmto spôsobom.

- Absencia spätnej väzby - jednosmerná komunikácia je rýchlejšia, dvojsmerná komunikácia je presnejšia. Pre lepšie pochopenie a spoločný prístup k riešeniu úlohy je pre odosielatel’a a príjemcu dôležitejšia obojstranná komunikácia.

Prekážky (bariéry) v komunikácii možno rozdelit' do niekol'kých skupín:

- Bariéry vnímania:

- environmentálne stimuly

- postoje a hodnoty príjemcu

- potreby a očakávania príjemcu

- Bariéry pochopenia:

- jazyk, sémantické problémy

- schopnost' príjemcu počúvat' a prijímat' zvlášt' tie správy (odkazy), ktoré sú ohrozené v dôsledku jeho alebo jej ponímania

- príliš dlhá, obšírna komunikácia

- účinok statusu

- Bariéry prijatia:

- predsudky

- individuálne konflikty medzi odosielatel’om a príjemcom 
Jedným z možných spôsobov ako redukovat' dôsledky uvedených prekážok je zabezpečovat' $\mathrm{v}$ priebehu komunikačného procesu dôslednú kontrolu reálnosti odkazu (obrázok 1).

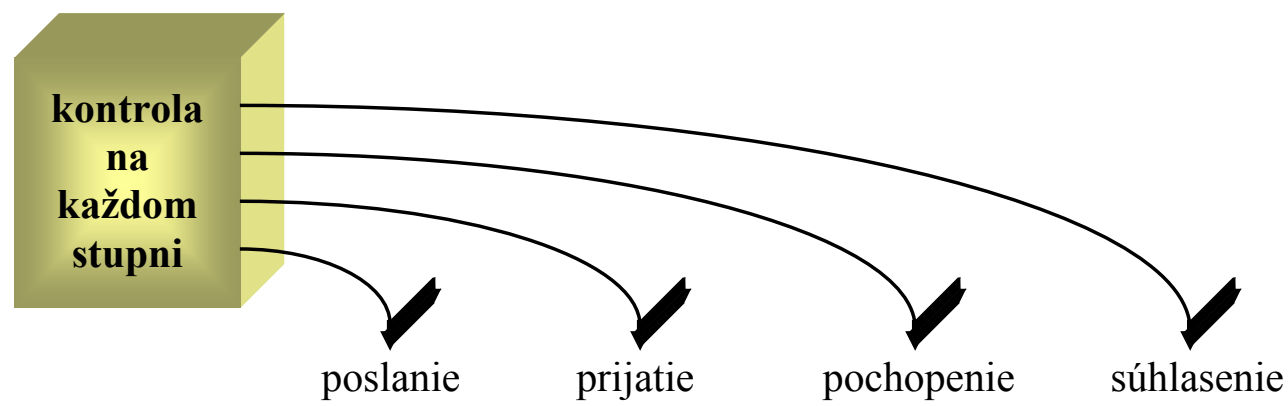

Obr. 1 Efektívna komunikácia [5]

Na potlačenie prekážok v komunikácii sa používajú tri metódy:

- Spätné pripájanie znamená, že osoba, ktorá vydala informáciu sa kontrolnými otázkami presvedčí o tom, či príjemca správne pochopil informáciu. Najjednoduchším spôsobom je požiadat' príjemcu o zopakovanie informácie.

- Redundancia - nadbytočnost', neznamená poskytnutie novej informácie. Ide iba o zopakovanie pôvodnej informácie, aby si príjemca uvedomil jej význam. Takýto postup používajú často učitelia, ked' dôležitú čast' z preberanej látky zopakujú ešte raz, napr. definíciu.

- Empatia predstavuje vcítenie sa do pozície príjemcu. Chápat' informáciu mozgom príjemcu, vidiet' informáciu opät' očami príjemcu. Tento postup platí aj opačne, ked' sa príjemca snaží pochopit' osobu, ktorá je prameňom informácie. Konkrétnym príkladom absencie empatie môže byt' situácia, ked' sa v jazykovo cudzom prostredí môžeme dohovorit' $\mathrm{s}$ podpriemernými jazykovými schopnost’ami a prihovoríme sa človeku, ktorý nevyniká ochotou. V prípade, že máme št’astie, človek, ktorý k nám prejavuje empatiu pochopí aj náš chabo vyslovený problém.

\section{Marketingová komunikácia}

Marketingová komunikácia predstavuje kontrolovaný, integrovaný program komunikačných metód a prostriedkov určených na prezentovanie podniku a jeho výkonov budúcim zákazníkom, ktorý sprostredkuje vlastnosti produktov a ich schopnost' uspokojovat' potreby $\mathrm{s}$ ciel'om podnietit' predaj, a tým prispievat' $\mathrm{k}$ dlhodobému ziskovému výkonu podniku. Predstavuje súbor rôznych metód, ktoré stimulujú uskutočnenie nákupu, a ktoré môžu byt' orientované na konečných spotrebitel’ov, ako i na sprostredkujúce medzičlánky.

\section{Základnými úlohami marketingovej komunikácie sú:}

- zabezpečit' komunikáciu výrobcu, predajcu alebo poskytovatel'a produktu so zákazníkom a s ostatnými kl’účovými trhmi,

- zvýšit' významnost' produktov,

- pomáhat' zákazníkom lepšie sa orientovat' na trhu a hodnotit' celkovú ponuku produktov. 
Zásadnými úlohami pri integrácii nástrojov marketingovej komunikácie sú:

- identifikovat' ciel'ovú skupinu, na ktorú bude úsilie zamerané,

- stanovit' ciele propagácie,

- podporit' umiestnenie produktu,

- vyvinút' a posilnit' značku a imidž,

- informovat' zákazníkov o službe a jej základných vlastnostiach,

- presvedčit' zákazníkov ku kúpe,

- ponúkanú službu zákazníkom priebežne pripomínat',

- pripravit’ správu, ktorá sa opiera o poznanie reakcie zákazníka,

- vybrat' komunikačný mix, ktorý pozostáva z vhodných komunikačných nástrojov.

Faktory ovplyvňujúce marketingovú komunikáciu:

- Je produkt v ziskovom alebo neziskovom sektore?

- Je intenzita konkurencie vysoká alebo nízka?

- Je geografický dosah produktu vel'ký alebo malý?

- Existujú v danom sektore zvyklosti, ktoré predurčujú nástroje marketingovej komunikácie?

- Je úroveň vedomostí a skúseností manažérov v tejto oblasti vysoká alebo nízka?

Hlavným poslaním komunikačného mixu je predanie celej škály informácí́ zákazníkom alebo distribučným cestám. Týmto chceme zákazníka informovat', že je predávaný určitý produkt, ktorého spotreba prináša uspokojenie.

V súčasnej dobe stále viac podnikov začína uplatňovat' program integrovanej marketingovej komunikácie (IMC). Ide o spôsob plánovania marketingovej komunikácie, ktorý si uvedomuje pridanú hodnotu jednotného plánu, ktorý hodnotí strategickú úlohu celej škály komunikačných nástrojov a tieto kombinuje tak, aby dosiahol zrozumitel'nost', ucelenost' a maximálny vplyv komunikácie prostredníctvom dokonalej integrácie jednotlivých správ.

Podniky služieb sú často „vycvičené“ na produkciu mnohostranných marketingových kampaní, ktoré za určitých okolností vôbec neplnia svoj účel. Tento problém sa dá vyriešit' tým, že vo firmách je určený tzv. systémový architekt - marketingový manažér s vel'kou zodpovednost'ou za všetky aspekty marketingovej kampane. Architekt musí rozumiet' podnikovým ciel'om, poznat' marketingový algoritmus a mat' autoritu potrebnú na riadenie programov marketingovej komunikácie. Jeho hlavným ciel’om je zostavenie „štíhleho“ a súdržného marketingového tímu.

Marketingová komunikácia a jej samotné úsilie je odlišné na spotrebitel'ských a na priemyselných trhoch. Podniky, ktoré podnikajú s výrobnými prostriedkami najväčší dôraz a teda aj najvyššie výdavky vynakladajú na osobný predaj, podporu predaja, reklamu a public relations. 


\section{Spotrebitel'ský trh}

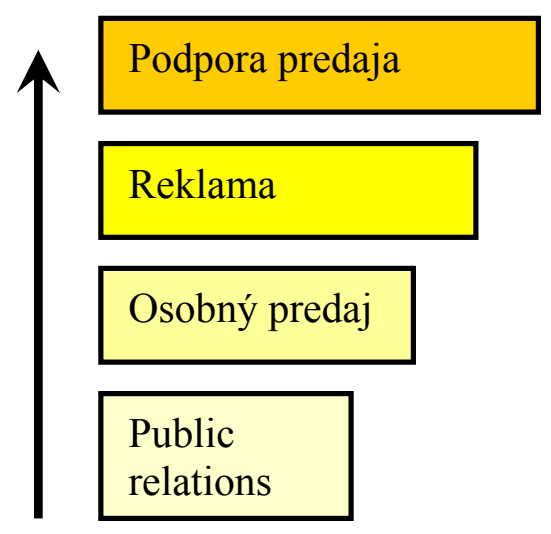

\section{Priemyselný trh}

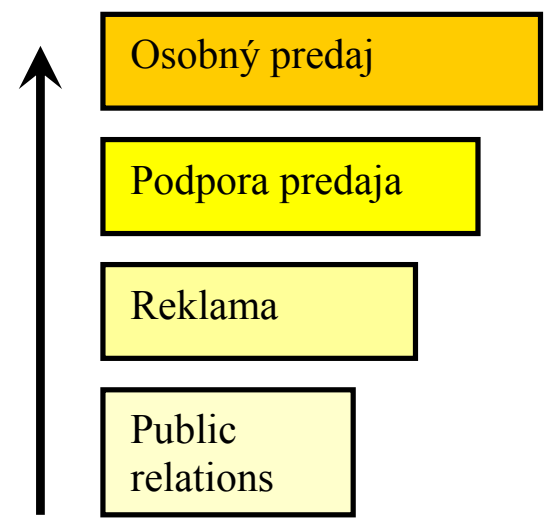

Obr. 2 Porovnanie relatívnych výdavkov na nástroje marketingovej komunikácie na spotrebitel'ských a priemyselných trhoch [1]

Všeobecne je osobný predaj najčastejšie používaný u zložitého, nákladného a rizikového tovaru a na trhoch, kde pôsobí menšie množstvo väčších predajcov.

\section{Proces tvorby marketingového komunikačného mixu}

Prípravu marketingového komunikačného mixu je možné rozdelit' do niekol'kých krokov, ako to znázorňuje obrázok 3.

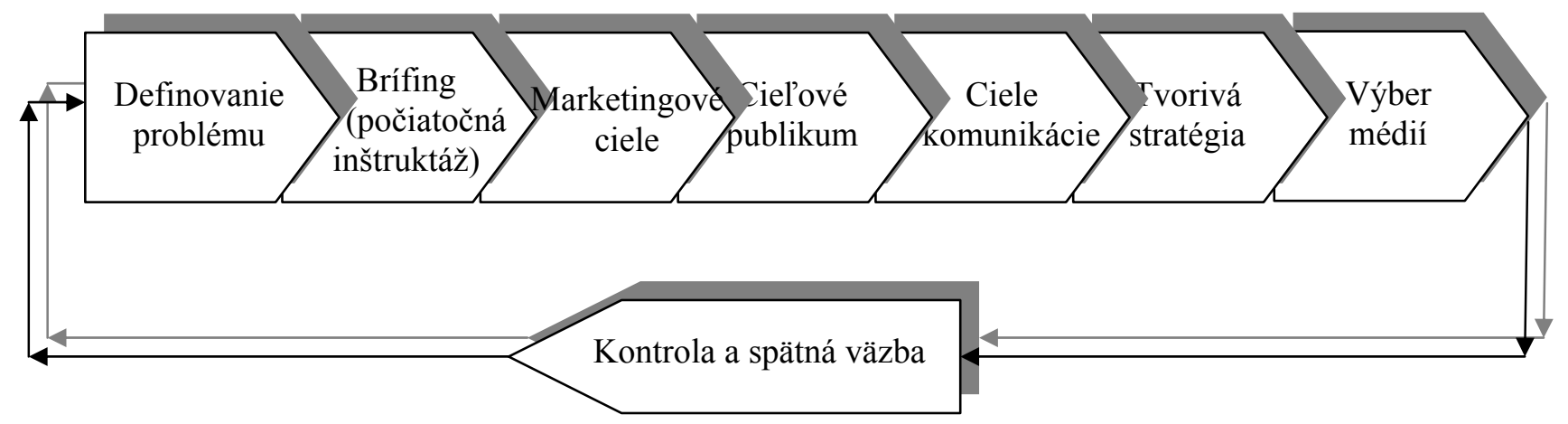

Obr. 3 Proces marketingového komunikačného mixu [2]

Ak sa reklamná kampaň vykonáva profesionálne, ide o investíciu, nie o výdavky. $\mathrm{O}$ rozsahu vynaložených prostriedkov rozhoduje vrcholový manažment alebo riaditel' pre marketing, so zretel’om na obchodný a marketingový plán organizácie.

Pri tvorbe rozpočtu marketingovej komunikácie je potrebné dodržiavat' určité zásady a prístupy. V zásade existuje niekol'ko prístupov a metód používaných pri tvorbe rozpočtu na marketingovú komunikáciu (tabul'ka 1). 
Tab. 1 Tvorba rozpočtu marketingovej komunikácie [1]

\begin{tabular}{|c|c|c|}
\hline $\begin{array}{c}\text { Používané } \\
\text { metódy }\end{array}$ & Charakteristika metódy & Náplň používanej metódy \\
\hline $\begin{array}{l}\text { Podl'a } \\
\text { stanovených } \\
\text { ciel'ov a } \\
\text { reklamných médii }\end{array}$ & $\begin{array}{l}\text { - ide o najprepracovanejšiu metódu } \\
\text { (pri podnikoch s malým rozpočtom } \\
\text { môže byt' nereálna). }\end{array}$ & $\begin{array}{l}\text { Metóda predpokladá presné } \\
\text { určenie ciel'ov a postupnost' krokov, } \\
\text { ktoré k nim vedú. Výsledná suma sa } \\
\text { rovná súčtom nákladov na jednotlivé } \\
\text { medzistupne. }\end{array}$ \\
\hline $\begin{array}{l}\text { Podl'a podielu z } \\
\text { tržieb }\end{array}$ & $\begin{array}{l}\text { - rozpočet sa stanoví ako pomerná } \\
\text { čast' z tržieb na základe budúceho } \\
\text { trendu predaja vyvolaného reklamou. }\end{array}$ & $\begin{array}{l}\text { Ak je možné vopred určit' } \\
\text { priamu väzbu medzi predajom a } \\
\text { marketingovou komunikáciou, potom } \\
\text { sa táto metóda javí ako vel'mi } \\
\text { jednoduchá. Nie je vhodná pri } \\
\text { uvádzaní nových produktov/služieb a } \\
\text { pri vel'mi nízkych rozpočtoch. }\end{array}$ \\
\hline $\begin{array}{l}\text { Podl'a } \\
\text { konkurencie }\end{array}$ & $\begin{array}{l}\text { - objem rozpočtu dosahuje alebo } \\
\text { prevyšuje rozpočet konkurencie } \mathrm{s} \\
\text { ciel'om udržat' doterajší podiel na trhu. }\end{array}$ & \begin{tabular}{l}
\multicolumn{4}{c}{ Organizácia môže určit' vel'kost' } \\
rozpočtu ako priemernú hodnotu \\
nákladov na marketingovú \\
komunikáciu v odvetví, v ktorom \\
podniká, aby zabránila vzniku \\
„reklamnej vojny“. Takto určený \\
rozpočet však nemusí zodpovedat' \\
prijatej komunikačnej stratégii \\
podniku.
\end{tabular} \\
\hline $\begin{array}{l}\text { Podl'a } \\
\text { dostupných } \\
\text { prostriedkov }\end{array}$ & $\begin{array}{l}\text { - rozpočet sa stanoví na základe } \\
\text { prostriedkov, ktoré má organizácia na } \\
\text { tento účel k dispozícii. Teda rozpočtu } \\
\text { sa musí prispôsobit finančná } \\
\text { náročnost' } \\
\text { komunikácie. }\end{array}$ & \begin{tabular}{l}
\multicolumn{1}{c}{ Rozpočet nesmie ohrozit' } \\
finančnú likviditu podniku a zisk pre \\
dané obdobie. Firma ich vynaloží bez \\
ohl'adu na to, či stanovené ciele \\
vyžadujú vyššie alebo nižšie \\
investície.
\end{tabular} \\
\hline
\end{tabular}

Tvorbu rozpočtu ovplyvňujú nasledujúce faktory:

- štádium životného cyklu služby - nové služby vyžadujú väčšinou väčší objem prostriedkov pre získanie náklonnosti zákazníka,

- podiel na trhu - služby s vysokým podielom na trhu potrebujú viac komunikácie so zákazníkmi ako služby s menším podielom,

- konkurencia a presýtenost reklamou - trh s viacerými konkurentmi vyžaduje výraznejšiu marketingovú komunikáciu, čo spôsobuje zvyšovanie výdavkov,

- frekvencia marketingovej komunikácie - čím sa zvyšuje potreba frekvencie komunikácie so zákazníkom, tým vo všeobecnosti stúpa rozpočet na marketingovú komunikáciu,

- diferenciácia služby - podobné služby vyžadujú väčšiu reklamnú podporu, aby sa rozlíšili.

\section{Záver}

Integrácia marketingu do činnosti a organizácie podniku, ale aj do myslenia jeho pracovníkov, je kl'účom k dosiahnutiu takej reakcie podniku, ktorá podniku zabezpečí trvalý predstih pred konkurenciou. 
Súčast'ou podnikovej stratégie musí byt' nielen marketingová stratégia, ale aj inovačná a technologická stratégia, ktorých výsledkom sú výrobky, ktoré zodpovedajú trendom dopytu a finančná stratégia, ktorá $v$ dostatočnom predstihu zabezpečuje finančné zdroje.

\section{Literatúra}

[1] CSIKÓSOVÁ, A.: Priemyselný marketing. Košice : TU, 2005. ISBN 80-8073-416-X.

[2] CSIKÓSOVÁ, A.: Základy marketingu. Košice : Elfa, 2001. ISBN 80-88964-90-3.

[3] DE PELSMACKER, P.: Marketingová komunikace. Praha : Grada Publishing 2003. ISBN 80-247-0254-1.

[4] MIHOK, J. - VIDOVÁ, J.: Riadenie podniku v kríze. Košice : SjF TU v Košiciach, 2006. ISBN 80-8073-533-6.

[5] SZARKOVÁ, M.: Komunikácia v marketingu. Bratislava : Ekonóm, 2005. ISBN 80225-2097-7.

\section{Grantová podpora}

Príspevok bol pripravený v rámci riešenia grantovej úlohy VEGA 1/2198/05 Využitie internetového marketingu ako nástroja pre zvýšenie konkurencieschopnosti domácich subjektov po vstupe SR do EÚ. 